\title{
Conflicts over Locally Unwanted Land Uses (LULUs): Reasons and solutions for case studies in Izmir (Turkey)
}

\author{
Ilgi Atay Kaya ${ }^{\mathrm{a}, *}$, Nursen Kaya Erol ${ }^{\mathrm{b}}$ \\ a Dokuz Eylul University, Faculty of Architecture, Department of City and Regional Planning, Tinaztepe Kampusu, Dogus Cad. No:209, 35160 Buca, Izmir, \\ Türkiye \\ ${ }^{\mathrm{b}}$ Izmir Institute of Technology, Faculty of Architecture, Department of City and Regional Planning, 35430 Urla, Izmir, Türkiye
}

\section{A R T I C L E I N F O}

\section{Article history:}

Received 21 July 2015

Received in revised form 4 July 2016

Accepted 14 July 2016

Available online 25 July 2016

\section{Keywords:}

Locally Unwanted Land Uses (LULUs)

Land use planning

Conflict resolution

Solid waste facilities

Fisheries

Quarries

\begin{abstract}
A B S T R A C T
Land use planning affects many different and usually conflicting interests. While every land use planning decision has a potential of creating conflicts, Locally Unwanted Land Uses (LULUs) are the most conflict facing subjects in urban land use planning processes. This paper aims to answer the question "what are the reasons and solutions for conflicts in the planning processes of LULUs". This paper is based on a research examining LULU cases in İmir, Turkey including solid waste facilities, fisheries and quarries to find out the reasons and the solutions for LULU conflicts. The research findings suggest that the conflicts stem not only from negative effects of LULUs on environment and community but also from procedural deficiencies such as lack of knowledge and lack of trust. The findings also call for planning processes with more consideration of local level and public participation seeking for consensus. Meanwhile, the conclusions underline the limitations for the success of participatory processes in which conflicts are resolved with attempts including symbolic benefits rather than considering exact interests of local people.
\end{abstract} (c) 2016 Elsevier Ltd. All rights reserved.

\section{Introduction}

Land use planning is both a technical and a political process in which many different interest groups are affected by planning decisions (Kaiser et al., 1995; Chabot and Duhaime, 1998). The interest groups include elected and appointed officials, developers and landowners, local residents, representatives of special interests such as neighborhood preservation and environmental conservation and land planners (Kaiser et al., 1995; Jones et al., 2005), and other people affected by planning decisions. Land use planning faces with conflicts (Jones et al., 2005; Peltonen and Sairinen, 2010) because of these differing interests.

Conflicts emerge in land use planning especially while dealing with Locally Unwanted Land Uses (LULUs). LULUs are land uses with a potential of facing local conflicts in their site selection processes. They are land uses or development projects which "may be regionally or nationally needed or wanted but are considered objectionable by many people who live near them" (Popper, 1985) because of their negative externalities such as being noisy, dan-

\footnotetext{
* Corresponding author.

E-mail addresses: ilgiatay@gmail.com (ì. Atay Kaya),nursenkaya@iyte.edu.tr (N. Kaya Erol).
}

gerous, ugly, smelly; polluting; increasing traffic; and lowering property values (Popper, 1983, 1985; Nordenstam, 1994; Peyton, 2007). People affected by such externalities usually oppose to them (Popper, 1985; Ishizaka and Tanaka, 2003; Rogge et al., 2011).

Recent researches showed that the problems in site selection processes of LULUs are usual in many countries as well as in Turkey. While many studies proposed site selection methods such as multicriteria analysis methods (Vasiloglou, 2004; Banar et al., 2006; Ekmekcioglu et al., 2010), many other studies focused on conflicts in the site selection processes of LULUs. They tried to find out the reasons for the conflicts (Llurdes et al., 2003; Chung et al., 2008; Kaliampakos et al., 2011), factors affecting acceptance of land uses (Sellers, 1993; Steelman and Carmin, 1998) and ways to solve conflicts (Ishizaka and Tanaka, 2003; Llurdes et al., 2003; Kikuchi and Gerardo, 2009; Kaliampakos et al., 2011; Chiou et al., 2011; Simsek et al., 2014). These studies successfully exemplified the theoretical debates in their case areas; however, only a few studies made a comparison of various LULU types. Besides, only a few discussed the relationship between planning process and land use conflicts by using examples. The researches in Turkey including the cases of NIMBY syndrome related with LULUs (Palabiyık et al., 2010), site selection methods of unwanted land uses without focusing on their conflicts (Banar et al., 2006; Ekmekcioglu et al., 2010), a mediation practice in resolving the disputes about power 
plant project (Müezzinoğlu, 2000), are examples of the attempts to evaluate the conflict resolution practices of Turkey. The legislation in Turkey is claimed to inadequately handle the collaborative approaches, participation and alternative dispute resolution techniques (Ozcevik et al., 2010; Yılmaz, 2012). Rather than legislations, informal mediation practices are used in Turkish society when honor and self-respect are at stake (Yilmaz, 2012).

This paper is based on a research examining 27 LULU cases in İzmir, Turkey (Atay Kaya, 2014). The case studies include examples of three different LULU types experiencing three different site selection processes. The research examines solid waste facilities, fisheries and quarries which might be considered as the most frequently mentioned LULU conflicts in İzmir in recent years. With this study, we aim to find out the reasons for conflicts and to emphasize the issues to be considered in planning processes for preventing or resolving these conflicts in İzmir case.

\section{Planning for LULUs}

LULUs include most of the land use categories such as industry, transportation, technical and social infrastructure and housing. While not every land use type in these categories is a problem, some of them like low income housing, slums and shelters for the homeless for housing category or drug treatment centers and mental health facilities for health category are not desirable for the neighboring community.

LULUs are mostly related with NIMBY (not in my backyard) movement (Schively, 2007; Peyton, 2007). People having NIMBY approach are mostly aware of the need of the facility but do not want it near themselves in their neighborhoods, districts or villages. When there is a NIMBY movement against LULUs, the land allocation process becomes more complicated. On the other hand, it has a progressive effect on decisions by addressing issues weakly concerned by local communities.

Resolving conflicts requires at first a deep understanding of their reasons. Reasons may be substantial and related with characteristics of conflicts. Levels, focuses, types of conflict, parties involved, strategies of opponents, and impacts of conflicts on community indicate characteristics of conflicts (Kaiser et al., 1995; Jones et al., 2005; Lam and Woo, 2009; Whetten and Cameron, 2011). Conflicts may have low or high levels of disagreement. They may be external or internal. They may occur between two parties or within large groups of people. These issues provide insights for understanding characteristics of land use conflicts. LULU conflicts can be caused not only by their environmental impacts such as odor or noise but also by other procedural factors such as distrust, political reasons and lack of knowledge. Therefore understanding these factors affecting them is essential for conflict resolution (Popper, 1985; Bassett et al., 2002; Ishizaka and Tanaka, 2003; Lam and Woo, 2009; von der Dunk et al., 2011; Rogge et al., 2011; Whetten and Cameron, 2011).

For a smooth process there is a need for utilizing conflict minimization and resolution strategies. The strategies based on technical and ethical concerns include competent siting practice, considering local, environmental, social criteria, developing trust, utilizing from multi-disciplinary approach (Nordenstam, 1994; Been, 1994; Forester, 1999; Carpenter, 1999; Elliott et al., 2003; Healey, 2003; Klosterman, 2003; Llurdes et al., 2003), and using compensation and technology (Ozawa, 1999; Lam and Woo, 2009; Chiou et al., 2011; Lesbirel, 2011). Besides, participatory approaches suggest conflict resolution methods such as mediation, facilitation, negotiation, collaboration and consensus building (Forester, 1999; Innes and Booher, 1999; Straus, 1999; Andrew, 2001; Margerum, 2002; Goldstein and Butler, 2010; Cullen et al., 2010).

\section{LULUs in İzmir case}

With a total population of 4.168 .415 (TurkStat, 2015) İzmir is the third largest populated city in Turkey. Composed of 30 districts this metropolitan city involves 35 conflict facing LULU types. Among those, three LULUs with ongoing site selection conflicts are examined in this study (Fig. 1):

1. Solid waste facility cases: for this type the study examines the existing solid waste facility in Harmandalı and proposed areas in Torbalı, Menemen, Gökdere-Kaynaklar, Menderes, Yamanlar and Ödemiş. The existing facility built in 1992 had completed its capacity in 2007. Since then protests have been lasting to close the area as soon as possible. On the other hand, İzmir Metropolitan Municipality (IMM) is searching for alternative sites but could not finalize the process as the proposed locations are not accepted by their localities.

2. Fishery cases: the study examined the fisheries in Demircili, Sığacık, Saip-Ambarseki, Küçükbahçe, Ildırı-Gerence and Mordoğan. A notification about their location criteria is published in 2007 and a protocol determining potential fishery locations is signed in 2008. Despite notifications about their locations, transfer to deeper water and permission cancellations, protests remain since 2005 with reasons such as sea pollution and effects to tourism.

3. Quarry cases: the conflict facing quarries are located or proposed to be located in Germiyan, Yağcılar, Nohutalan, Özbek, Karaburun, Kösedere, Pınarbaşı, Belkahve, Gökdere-Kaynaklar, Çakmaklı, Yenmiş-Akalan-Ansızca, Çambel, Karakuyu-YeniköyÇileme and Ahmetbeyli. The conflicts about the quarries began in Belkahve in 1992 and resolved through their transfer to a more acceptable location in 2010; however the conflicts in other locations continue.

\subsection{Method}

The research starts with the question "What are the reasons of and solutions for conflicts in planning processes of solid waste facilities, fisheries and quarries in İzmir cases?". To answer this question the study applied qualitative techniques including document analyses, media search, in-depth interviews and content analysis. The data is collected from the archives of local institutions, chambers and newspapers. İzmir Metropolitan Municipality, Provincial Directorate of Environment and Urbanism, Provincial Directorate, İzmir Bar Association and İzmir Branches of Chamber of City Planners and Chamber of Environmental Engineers are visited. The web-based archives of national and local newspapers, related organizations and blogs are searched. The documents including reports, books, plans, photos, inventories, press releases, court decisions are searched and the opinions of the experts and local people are noted.

This preliminary research guided to determine the case locations and interviewees. 35 conflict facing LULU types are found and ranked due to the conflicts' intensities. Among those, firstly nine LULUs which were protested by local people with meetings and took place in media more are selected. These are mines and quarries, electricity generating stations, communication towers, watching stations, loud entertainment facilities, dams, shopping malls, solid waste facilities and fisheries. Then three of them - solid waste facilities, fisheries and quarries- are chosen. Rather than all solid waste facilities, fisheries or quarries in the city the study considered only conflict facing LULUs. Seven conflict cases about solid waste facilities, six cases about fisheries and fourteen cases about quarries are found (Fig. 2). 

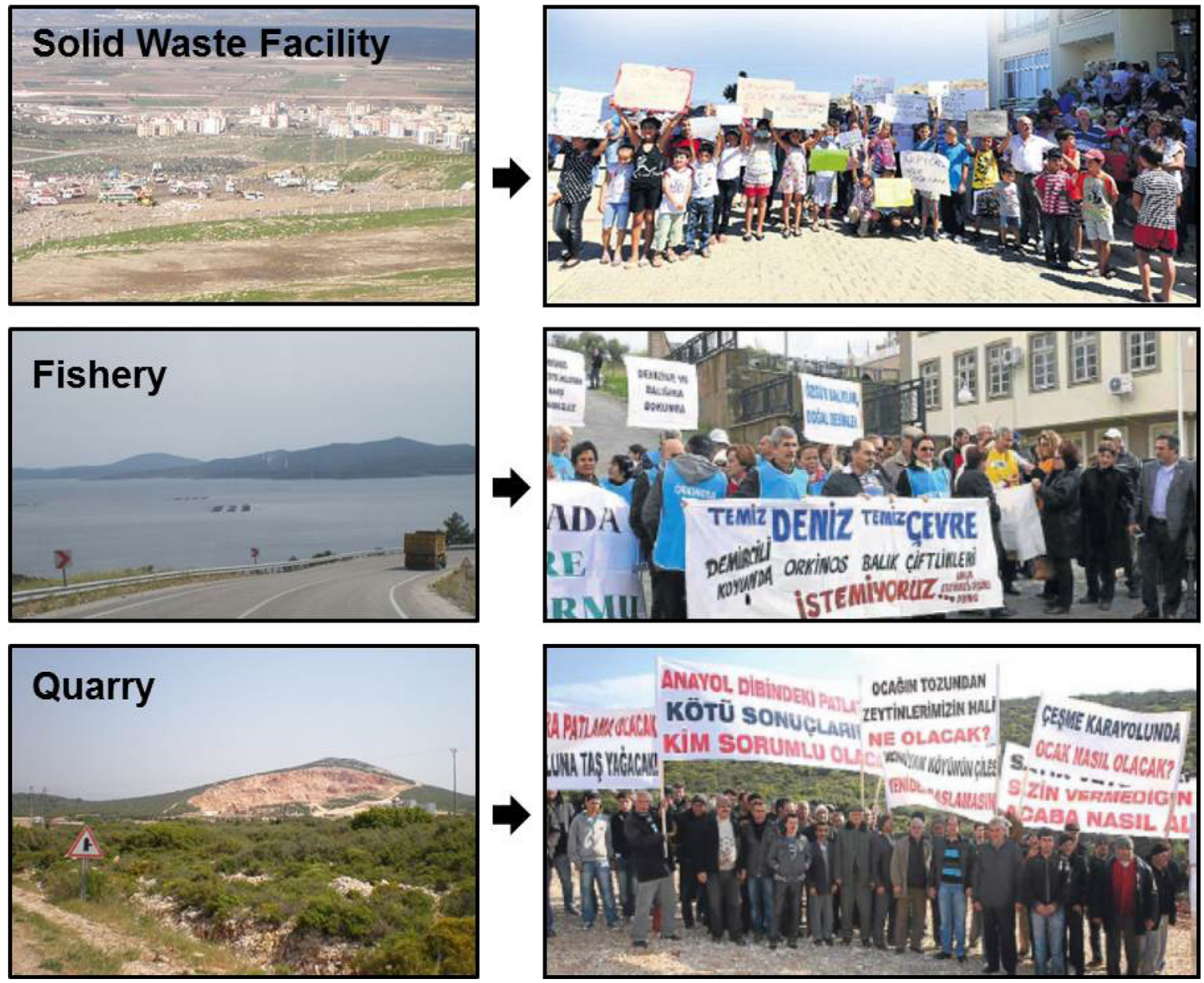

Fig. 1. Three conflict facing LULUs in İzmir (Photos by authors on the left; photos from Milliyet archive (Milliyet, 2004-2012) on the right).

Table 1

Number of interviewees due to cases and groups.

\begin{tabular}{|c|c|c|c|c|c|c|c|c|}
\hline \multirow[t]{2}{*}{ Cases } & \multicolumn{8}{|l|}{ Interviewed Groups } \\
\hline & Metropolitan Municipality & Public Institution & District Municipality & Headmen (Muhtar) & Private sector & NGOs & University & Total \\
\hline Solid Waste Facilities & 6 & 6 & 8 & 5 & 0 & 4 & 1 & 30 \\
\hline Fisheries & 0 & 5 & 7 & 9 & 2 & 6 & 3 & 32 \\
\hline Quarries & 0 & 5 & 11 & 14 & 3 & 4 & 1 & 38 \\
\hline Total without duplications*) & 6 & 8 & 17 & 25 & 5 & 7 & 4 & 72 \\
\hline
\end{tabular}

" Duplications occur when an interviewee answers for more than one cases.

The research aimed to reach the knowledge and opinions of different people from different parties and to facilitate the comparison of various cases by using a set list of questions. With this aim indepth structured interview technique is employed. 19 open-ended questions (Appendix A) are asked to all 72 interviewees from the parties involved in the process including public institutions, local people, non-governmental organizations, private companies and universities (Table 1). For a deep understanding of the conflicts the case studies are examined through content analysis.

The reasons and proposals are discussed on case findings by referring to related literature. The following findings include both actors' perspectives and our observations.

\subsection{Reasons for conflicts}

Conflicts in three LULU cases in İzmir are caused by several substantive and procedural factors. In substantive and procedural distinction by substantive we mean the reasons depending on out- comes and by procedural we mean the reasons on processes as in the distributional and procedural justice distinction (Been, 1994; Cutter, 1995). While the substantive reasons are based on characteristics of LULUs such as types, locations, impacts of them and their economic or political outcomes, the procedural reasons are related with decision making process such as decision making approach, technical procedures, role of actors in the process.

\subsubsection{Substantive reasons}

One category of substantive reasons for conflicts are LULU type related reasons including three issues: (i) some LULU types are private investments, so conceived as a way of getting private revenue from natural resources as in fishery and quarry cases, (ii) some types are not considered as necessities for the community (i.e. fisheries), (iii) for some LULU types although they are not considered as problem themselves, their additional facilities are opposed by local people (i.e. logistic facilities of quarries). 


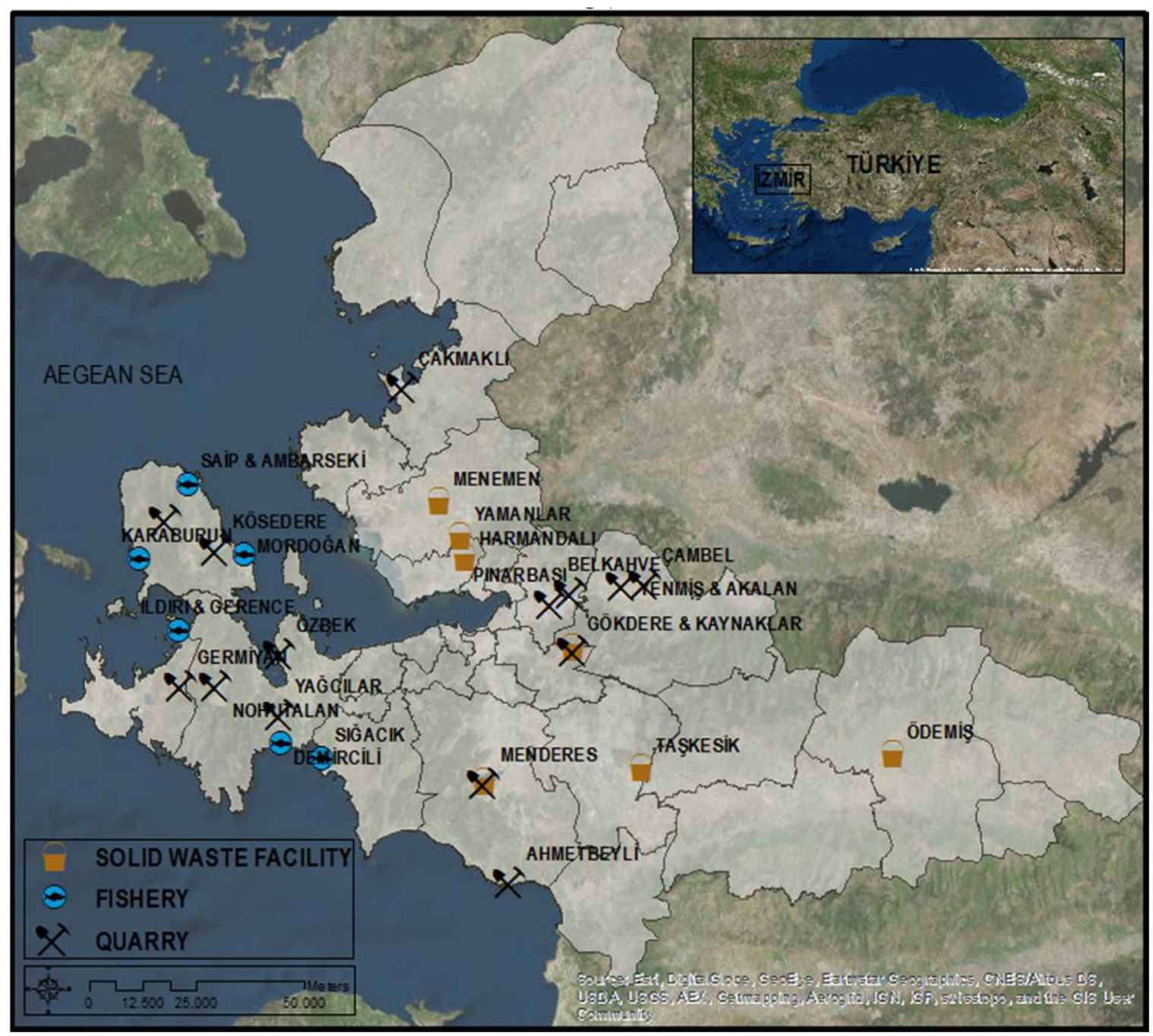

Fig. 2. Locations of three conflict facing LULUs in İzmir (produced by authors on Google Earth image).

A second substantive reason is LULU location. Putting a facility in the wrong location is one of the failures of the siting processes (O'Hare et al., 1983). Location based conflict creating issues are (i) geologic, topographic and other natural characteristics of the sites hosting LULUs as in fisheries in closed bays or solid waste facilities in sites with permeable grounds, (ii) LULUs near sensitive land uses such as residential area, agricultural land, forests and olive groves (i.e. solid waste facility proposal near Tahtalı Basin Conservation Area in Menderes, quarry proposal near antique city in Ahmetbeyli and fisheries near fertility zones of seals in Karaburun), (iii) LULUs close to administrative boundaries may affect the people residing in neighboring settlements and not considered in decision making processes (i.e. fisheries in Sığacık located in Urla boundaries), (iv) the possibility of losing the positive image of the district or city (i.e. Citta Slow image in Sığacık), (v) LULUs located on privately owned lands objected by those owners (i.e. solid waste facility in Ödemiş).

The third substantive reason is based on LULU impacts such as impact to ecosystem, environmental pollution, possible diseases caused by pollution, dust, noise, odor problems, visual pollution, environmental stress, traffic problems and psychological effects (i.e. odor and mosquito problems, seagulls, explosion risk of the existing disposal site in Harmandall, poured waste from waste transfer vehicles, proximity of the proposed solid waste facility to public sports area and youth center in Yamanlar in solid waste facilities; sea pollution, eradication of species, damage to seals and disturbance of quietness in fisheries; and dust and vibrations, possible damage to 1000 years old trees in Kaynaklar, an increase in cancer cases in Yağcılar, electrical energy cuts, damage in roads in quarries; economic costs including value lost in lands, effect to local sectors such as fishing and livestock farming).

The fourth reason is related with political and economic expectations and outcomes (Campbell et al., 2000). Some groups having different political approaches than IMM opposed to their proposals (i.e. solid waste facility). Similarly, groups having different political positions than the central government opposed to the actions of their policies (i.e. quarries). Competing interests of various sectors (i.e. fisheries vs. tourism), rival companies of the same sector (i.e. quarries) and expectation of personal economic gains increased LULU conflicts.

\subsubsection{Procedural Reasons}

Procedural reasons affect conflicts as much as LULU characteristics based reasons. One of the procedural reasons is the decision making approach. The top-down decision making approaches cause conflicts (Rogge et al., 2011). Local people in many cases criticized the top-down approaches describing as decision making "from their offices" or "from Ankara" without investigating or seeing the site. An interviewee from Kemalpaşa Municipality said: "It is not asked to local. When only Ankara (central government) decides, some groups supporting the government 
can immediately complete their works. Mostly, local (people), local government and municipality should be active."

Conflicts about decision makers are several. While in solid waste cases local interviewees think that "the mayor and his friends" decide, in fisheries and quarries protestors criticize the process as the private companies decide the locations of their investments. Another issue is about the involvement of the planners as decision makers. Some groups criticized the decision making lacking planners which is perceived to result with site selections inappropriate to planning objectives. In solid waste facility cases, previous decisions were made within a planning process in which planners only control the decisions made by engineers; whereas recent decisions were made by a commission including planners. On the other hand, in fishery and quarry cases the site selection processes depended on permissions and the locations did not have to be included in urban plans. There was no role for planner in practice of fisheries and quarries. The participation meetings in Environmental Impact Assessment (EIA) process are told to be symbolic by some opponents. An academician from Faculty of Fisheries mentioned his negative impression about this meeting as:

"Ministry of Environment organized a meeting (to decide potential locations for fisheries) in Çeşme. All stakeholders attended to the meeting. Marine Counsellorship, Provincial Directorate of Agriculture, Military... The workshop took three days. In the last day, a counselor from Ankara came and announced the text in his hand. 9 Eylül University was there. I was participated from Ege University. Everything was a lie. They put all the stakeholders together and then a man comes and makes a text accepted. And he says 'is there any accepters and rejecters?'. They excluded universities from the signature list. Such antidemocratic. .."

Lack of open and transparent processes also face with conflict. Some opponents of solid waste facilities criticized the IMM not to be transparent in site selection process of solid waste facilities (i.e. Bornova).

Technical procedures and deficiencies are other procedural reasons. Some conflicts emerged because of the lack of investigation according to some groups. In Bornova solid waste facility case some actors were suspicious about the criteria of considering wind and sun directions in site selection. In Menemen solid waste case site selection was blamed to be done by looking from Google. Some LULUs faced conflicts because of temporal deficiencies like weaknesses in meeting deadlines (Kunreuther et al., 1991, 1993; Andrew, 2001), being late in their site decisions or time of informing local people. An alternative site to Harmandalı solid waste facility should be found before its capacity expired. Another technical deficiency is the inconsistency with existing plans/regulations. As some land use decisions are made incrementally (i.e. solid waste facilities) or only with permissions of some institutions (i.e. quarries) they may be inconsistent with upper scale plans.

Role of actors in the process is also regarded as one of the procedural reasons. Personal differences are one of the important sources of conflicts (Whetten and Cameron, 2011). Characteristics and perspectives of the actors, their approaches to the problem and to each other cause varieties in approaches within and between actor groups.

- Approaches of parties to the reasons of problems: opponent groups usually focused on the effects of LULUs to local people. Actors from IMM focused on technological developments. There were both opposing and supporting actors from public institutions who mainly emphasized the consistency with regulations. While some headmen (elected officials in villages or districts, mukhtars) told that fisheries increased the amount of fish hunted by local fishermen, some others told that they affected badly. Private sec- tor's critiques on the process were similar that they had to face protests although they acted appropriate to regulations. They called for government intervention and control for solving these problems.

- Approaches of parties to the level of disputes: some parties approached to conflicts as movements of all people living in the district whereas some parties approached to conflicts as small movements of a few shouting people (i.e. in Çakmaklı case headman told that all villagers oppose to quarries whereas interviewee from municipality told that $10-15$ people oppose to them). Prejudice was also a reason of conflicts for some actors. As LULUs are "unwanted", hearing their names may be enough for protesting in some cases (i.e. solid waste facility).

- Approaches of parties to other parties: approaches excluding or forcing local people increased conflicts. There was a problem about forcing and rude approaches in quarry cases. Even there were some headmen faced with threats of mine owners. Trust or distrust in government also affects the emergence of conflicts (O'Hare et al., 1983; Baxter et al., 1999; Ishizaka and Tanaka, 2003; Elliott et al., 2003; Lam and Woo, 2009). When local people did not trust to decision makers or the companies, the conflicts get bigger and harder. In some cases, local people did not believe that the precautions in EIA reports would be taken (i.e. quarries) and the promised technology would be used (i.e. solid waste facility). All groups stated distrust as underlying factor of conflicts. The distrust is usually related with existing bad examples such as the proximity of solid waste facility in Harmandalı to residential areas because of the development permissions given after its establishment, the irregular and technologically poor fisheries located in shallow water before the regulation, and quarries permitted without technical experts and environmental precautions by the previous regulation. A headman opposing one of the recent cases of the solid waste facility explained their opposition reason:

“We protested. Why? Because of that Izmir Metropolitan Municipality did not fulfill the promises. For example, level crossing and overpass were not built. (...) We will not be opposed in the event that Municipality will do (waste) facilities as he (the Mayor) said. It will have benefits for the district. We are against this because we do not trust Municipality."

On the contrary, another opponent interviewee in the same case told that there was no distrust and IMM had done the necessary feasibility.

- Effect of political actors: politicization of development issues (Bassett et al., 2002), lack of balance between parties (Andrew, 2001) and siting decisions influenced by political pressures (O'Hare et al., 1983) cause conflicts. The involvement of powerful political actors to manipulate the decisions in both site selection and conflict processes increased the local movements in the cases. It is said that potential fishery locations are decided by those actors. Also, Ministers explained that Torbalı was not suitable for solid waste facility. Change in decisions through those interventions arose the question of why they changed with political power if they were scientifically suitable.

- Effect of media: the role of media in conflicts (Bassett et al., 2002; Rogge et al., 2011) had two-fold effects in case studies. First, it increased the effectiveness and recognition of the local movements and protests. Second, it spread biased news directed by powerful sector groups (i.e. fisheries).

- Characteristics of the citizens in İzmir: people living in İzmir differed from many other cities in the country in terms of their responses and level of being oriented. Some interviewees told that the people of İzmir would not be quiet when they had 
problems; they would fight for their rights, take part in protests fearlessly and learn the ways of getting their rights.

- Actors' level of knowledge: the effect of inadequate information in conflicts (O'Hare et al., 1983; Rogge et al., 2011; Whetten and Cameron, 2011) interpreted in several ways in case studies. Some parties told that the people who know their rights participate in protests and others without knowledge do not. On the other hand, some parties told that they protest because they do not know the technology (i.e. solid waste facility) or characteristics of facilities (i.e. fisheries). The less information and knowledge interest groups have about the issue, the bigger problems get. In fishery cases, some parties including university, public institution and private sector blamed opponents to have wrong knowledge about the fisheries and their effects to seas. An engineer from Provincial Directorate of Agriculture mentioned:

"(People oppose to fisheries) because they are wrong informed. Because they think it pollutes; that is the apparent reason. The real reason is the share of place and not to dominate that place. The coast users do not want. There is nothing scientific that fisheries create pollution. There is knowledge pollution in this subject. The experts of this subject do not say it pollutes."

\subsection{Resolving conflicts: what is done, what should be done for Izmir cases?}

LULU conflicts can be minimized and resolved by using several strategies. Case studies are analyzed to clarify whether decision makers used these strategies. There are some attempts of decision makers to minimize and resolve conflicts. However in all cases these attempts were found insufficient by the majority. The following part presents main strategies applied by the decision makers and then discusses appropriate proposals for case studies.

The main conflict minimization and resolution strategies can be categorized in two groups:

\subsubsection{Strategies based on technical and ethical concerns}

(i) Recognition of conflicts is the preliminary step for solution (Forester, 1999); however, some interviewees from decision making institutions in case studies unconsciously told that the process was successful and smooth. Decision makers should be aware of the reasons for conflicts, conflicting parties and their interests.

(ii) Considering technical criteria is a requirement for competent siting practices (Nordenstam, 1994; Elliott et al., 2003). Decision makers in all cases paid attention to technical requirements for the facilities but had weaknesses in additional ethical principles and participatory approaches which are detailed in the following parts.

(iii) Principles of trust and equity: beside technical criteria there is also a need for fulfilling the principles of trust and equity to minimize conflicts about LULUs (O'Hare et al., 1983; Kunreuther et al., 1991, 1993; Nordenstam, 1994; Elliott et al., 2003; Llurdes et al., 2003). The LULU site selection criteria were technical; therefore, lacking the equity principle. However, there were no proofs of inequity in all cases. Developing trust was also a lacking principle in these three siting processes.

(iv) Consideration of post-siting and external effects (Been, 1994; Klosterman, 2003) and using mitigation measures (Lam and Woo, 2009) are essential for conflict minimization. Decision makers tend to improve the conditions of the existing facilities (i.e. rehabilitation project for Harmandalı solid waste facility, transfer of quarries in Belkahve to a more acceptable location without a visual pollution and transfer of fisheries to deeper water) and prefer to use new technology to solve conflicts.
There should be further precautions for external effects and regular controls.

(v) Community opposition can be prevented by considering the local concerns (Lam and Woo, 2009). Interests of local people are excluded from the current decision making processes in many cases for fisheries and quarries. It should be the responsibility of public institutions to consider local needs and interests.

(vi) Multi-disciplinary approaches (Nordenstam, 1994) and multi-criteria analysis methods (Vasiloglou, 2004; Banar et al., 2006; Ekmekcioglu et al., 2010) are required for technically competent decisions. EIA process involves various disciplines; however, planners are excluded from processes of fisheries and quarries. As the LULU concept relates various disciplines such as sociology, economy, environmental management and planning, their experts should be involved in decision making process and their criteria should be considered.

(vii) Comprehensiveness in approaching to the problem is needed to prevent conflicts. Location decisions of case studies are made with an incremental approach. Such large public service decisions should be made within the planning of the whole city; thus, further development permissions and neighboring districts would not be a problem.

(viii) Alternative zoning techniques (Roberts, 1988; Levy, 2000) may facilitate minimizing conflicts. Land use planning regulations in Turkey are so strict that do not provide chances for them. With such tools, hosting communities may get some incentives about densities, their development rights may be transferred, some contracts may specify the requirements for LULUs, and some impact fees may be paid for local costs.

(ix) Among various forms of compensation stated in literature (O'Hare et al., 1983; Lam and Woo, 2009; Chiou et al., 2011; Lesbirel, 2011), case studies in İzmir used strategies including providing a wanted land use, bargaining through money and improvement of facilities, and suggesting gifts. Money payments are unlikely to solve oppositions depending on interests 'not for sale' as O'Hare et al. (1983) mentioned. Decision makers should "focus on bargaining rather than gift-giving" (O'Hare et al., 1983). As the gifts were given without querying the exact interests of the opposing groups, this point fit Fainstein (2000) critique of negotiations including results satisfied the only symbolic benefits because of threat and bias in the process. Besides, negotiated compensation after fulfilling the mitigation and control measures may improve conflict resolution processes (O'Hare et al., 1983; Kunreuther et al., 1993).

\subsubsection{Strategies based on participatory process}

(i) Public participation, deliberation and learning: the ongoing decision making processes of many LULUs in Turkey is similar to the "decide-announce-defend" process (Ducsik, 1978, cited in O'Hare et al., 1983; Forester, 1999). However, it is a wrong way to choose a 'best site' and advocate it (O'Hare et al., 1983). The interviewee from Menemen Left Bank Irrigation Association had a similar opinion in which he said

\begin{abstract}
"Metropolitan Municipality should not decide alone. They should ensure consultation with nongovernmental organizations and local administrators. One location is not enough. It (waste facility) should be in four different locations. Opinions of everybody should be taken. If we live together we should decide together. Conflict resolution should have compromise."
\end{abstract}

Participatory approaches (Kunreuther et al., 1991; Nordenstam, 1994; Baxter et al., 1999; Carpenter, 1999; Forester, 1999; Margerum, 2002; Healey, 2003) could not be successfully man- 
aged by decision makers in the case studies. Indeed, the ongoing regulations do not require participatory planning processes except EIA process. The regulations were main guides for decision makers. The oppositions were not considered when the process is legally competent. EIA process is seen as a successful participatory process by some groups while for some others this participation was for the sake of formality but not an efficient one. Some opponents criticized the process in which private companies took 'EIA is not needed" report by showing their capacities lower.

As stated in the procedural reasons for conflicts, the participatory aspects of the meeting for potential fishery locations were in doubt. Although various parties took part and a protocol was signed, the interviews from public institutions, university and private sector criticized the process and told that negotiated decisions of the participants were not approved but the text brought by a counselor was signed. These negative judgements showed that the success of the participatory decision making attempt for fisheries was questionable.

Interviewees from IMM had different views on participatory conflict resolution. While one expert promoted participatory processes, another advocated that the decision maker has a right to select the site; therefore there is no need to compromise with local people if the site fulfills technical details and regulations. Similarly, another interviewee stated that there would be no solution if the process is participatory and another said that there would be people who cannot be convinced whichever participatory model is used. These perspectives might be the reason of lacking participatory approaches in solid waste cases. Their attempts include field trips and site visits which are regarded as factors preparing individuals to participate by Carpenter (1999). IMM organized site visits for Chambers and universities and a trip to Germany for good examples. These attempts increase positive opinions and overcome the conflict reason based on existing bad examples.

For effective deliberation there is a need for considering both substantive issues and procedural issues together (Forester, 1999). Decision makers in all İzmir cases tried to solve conflicts by mostly considering substantive reasons. In solid waste facility cases IMM attempted to persuade opponents by focusing on the technology and quality of the new facility. In quarry cases there are improvements of the bad conditions such as decreasing dust by using water or rehabilitation of the area after leaving. In fishery cases decision makers tried to explain that the fisheries did not pollute the seas. Many decision makers in İzmir cases do not consider procedural problems and do not propose procedural solutions enough.

(ii) Collaboration and consensus building: collaborative processes bringing stakeholders together to reach consensus agreement on decisions are promoted in several theories (Kunreuther et al., 1991; Innes and Booher, 1999; Elliott et al., 2003; Cullen et al., 2010). While some attempts approximating these approaches are tried in case studies, most of them failed because of using them after the decisions. Face-to-face interaction among stakeholders is a requirement of consensus building (Susskind and Cruikshank, 1987, 2006). Communication with stakeholders as a strategy for competent siting practices (Nordenstam, 1994; Elliott et al., 2003) was used in all three cases; however, it was done after the decision made. IMM organized some face-to-face meetings with local people and chambers to solve the conflicts about proposed location of new solid waste facility; however, the aim of these meetings were informing the opponents about decisions rather than building a consensus on a mutually acceptable decision. Chamber of City Planners told that these meetings had only a persuasion aim after making decisions and main focus was on technology rather than location. Nevertheless, it is a step for solution in terms of stakeholder involvement. On the other hand, some local people thought the
Mayor of IMM had collaboration suggestions; for example an interviewed headman told that: "The waste of Izmir. . . He (the Mayor of IMM) had to find a way out. He asked for help via media. He said "let"s find a location together."

Collaborating approach is more preferable in reaching all-gain agreements than the other kinds of approaches including forcing, accommodating, avoiding and compromising (Whetten and Cameron, 2011); however in case studies of all three LULUs, parties did not have this approach and they had avoiding, forcing and compromising approaches according to interviewees. An expert taking part in EIA process as a public officer explained approaches of private sector on conflict resolution with these words

"Entrepreneurs try to find a way for solution when they feel the response. They say that 'we shall listen to the public and their desires'. However, there are also some of them who do not make this. There are those who say 'this is my right in regulations and I will do this'. There are those who search for collaboration with local people."

Giving up is a kind of accommodating approach in which the party neglects its own needs and attempts to satisfy the needs of other parties (Whetten and Cameron, 2011). Some location decisions were given up by decision makers and some local interviewees regarded this attempt as a solution. Some decision makers told that cancellation of the decisions were not the result of protests but the result of technical or legal deficiencies. Besides, there is an effect of political interventions in the cancellation of decisions and approaches of parties in the conflicts. An interviewee from Karşıyaka Municipality explained this for the Yamanlar case:

"Maybe, the central office (of the political party) will say 'stop this dispute' and the issue will finish. It may not be done. Another location may be searched. We can not guess what happens in politics. Otherwise, Metropolitan Municipality is insisting. Karsıyaka Municipality is opposing. Compromise will happen only if there is a political thing (intervention)."

Consensus building increased the possibility and success of implementation of the decision with its attempt of finding mutual gain solutions (Susskind et al., 1999; Susskind and Cruikshank, 2006). There were some implementation problems in case studies especially in solid waste facility and quarry proposals which are cancelled again and again. Such problems may be solved with consensus building processes.

Factors affecting the success of consensus building badly include complexity and number of issues and people, threats (Elliott, 1999), metropolitan scale (Fainstein, 2000), distrust and lack of willingness to participate, contextual issues including cultural and social factors (Carpenter, 1999), perceptions on consensus building as a difficult and time-consuming process and external barriers disrupting the process (Susskind and Cruikshank, 2006), and power imbalances among stakeholders (Carpenter, 1999; Fainstein, 2000). (i) The case studies suffer from complexity where the participants in most of those disputes included the people from the entire districts or villages. (ii) There are two cases in which headmen told about threats from mining companies. (iii) Besides these barriers, participatory processes face obstacles in metropolitan areas as İzmir does. (iv) In the case studies, some opponents having no willingness to participate told that they will never give up their opposing positions. Besides, some interviewees from public institutions told that when the decisions were technically competent there will be nothing to be discussed with local people. Mining companies having their rights and powers from existing legal procedures do not mostly want to negotiate. This exemplifies "the existence of a better option available" described 
by Carpenter (1999). (v) The ethnic, racial, religious or economic backgrounds of interviewees were not asked in the case studies but there were some clues showing this variety and the effect of contextual issues. For example, one headman told that the quarries were supported by low income groups to get free materials from the companies; another headman told that the people not opposing to quarries were from an ethnically minority group. (vi) Interviewed decision makers in the case studies think that the processes would be difficult and time-consuming if all actors participate. (vii) Power imbalances among stakeholders affect the quality of consensus building process in fishery and quarry cases. Some interviewees suffered from the effect of powerful tourism sector in media and organization of local people against fisheries. The consensus point should be rethought here in terms of the quality of decisions. Are the decisions successful when there are no opponents? What if there are quieted opposing voices? Then, government authority in decision making and conflict resolution processes of LULUs is a need to provide the consideration of all voices in the community only if the government is socially sensitive.

For an effective process, facilities should be licensed after negotiations produce written 'siting agreements' as legal contracts between decision makers, developers and the community (O'Hare et al., 1983; Kunreuther et al., 1991, 1993; Susskind and Cruikshank, 2006). There are no such written documents produced in case studies in İzmir. Indeed, licensing procedures do not require such agreements. The timing and requirements of the licensing procedures should be rearranged. The need for a written commitment is emphasized in an interview with a headman as

"If the Metropolitan Municipality promises with a written commitment that it (the waste facility) will have latest technology and a notarized guarantee that there will be no odor, local people of the district may be persuaded."

(iii) Joint fact-finding: it increases trust and decreases disagreements about technical issues (Ehrmann and Stinson, 1999). There is a disagreement about information in case studies. In Yamanlar solid waste facility case, both decision maker and opponent municipalities hired technical expertise from universities about suitability or unsuitability of the facility. Also, in fishery cases there is a disagreement on polluting or not polluting effects of fisheries. A headman from Karaburun stated that the court expert investigating the fisheries was "a man of the company" and gave a report in favor of the company. The headman did not trust the reports of even the experts of the court. This situation fits the process that O'hare described as "opponents often claim that the local officials are 'in bed' with the developers". Therefore, inclusion of the parties into the fact finding process would solve trust problems in terms of technical issues.

(iv) Mediators and facilitators: they support dispute resolution processes (Forester, 1999; Susskind et al., 1999; Elliott, 1999; Straus, 1999; McCorkle and Reese, 2005; Susskind and Cruikshank, 2006) especially in cases suffering problems of communication and trust (Elliott, 1999) as in the case studies in İzmir. There are some informal types of mediation used by several parties such as public institutions and political actors. An interviewee from Provincial Directorate exemplified these interventions in quarry cases with these words

"When local people close the roads to hinder the facilities of mine quarries and prevent vehicles to work, bureaucrats and politicians intervenes and ensures the collaboration between local people and managers of mines and quarries."
Forester (1999) stated professional services firms doing this mediation and facilitation; however, this type of firms does not exist in Turkey but there are advisory bureaus serving for providing expert knowledge rather than serving mediation or facilitation. There are recent attempts to increase mediation processes in Turkey since the approval of related law (No. 6325) in 2012. A Mediation Directorate is established in Ministry of Justice. A new profession of mediators started to solve conflicts alternative to courts. However it is different from what Forester told because of several reasons: it is a public institution not a private firm or nonprofit organization, mediators are selected from only graduates of law faculties, and disputes related with public interests and requiring discovery and expert assistance are not allowed to be solved with mediation process and court decisions are needed for such situations. Therefore the existing mediation institution seems not suitable for solving LULU disputes and planners cannot act as mediators within the ongoing procedures and legislation. Planners should be included in mediation process in Turkey.

\subsection{Evaluation: intensity of conflicts}

Conflicts in the 27 LULU cases in İzmir had both similarities and differences. Main characteristics of the cases are summarized in Table 2. The distinguishing characteristics and reasons for these conflicts affected their intensities and results.

Parties involved in the conflicts mainly changed the intensity of conflicts. The amount of protesters, the varieties of parties and their organization level affect the duration of disputes and the way they are handled by the decision makers. The conflicts in cases with relatively small amount of local protesters (i.e. quarry cases of Çakmaklı, Çambel and Özbek, and solid waste facility case of Ödemiş) were not as intense as the conflicts in cases supported by external groups and famous people (i.e. fishery case of Sığacık). The intensity attracted media and the effect of media increased the amount of people involved (i.e. the secondary housing owners) and the intensity of conflicts in Sığacık case. Besides, organized protesters establishing initiatives increased the consideration of their interests by decision makers (i.e. solid waste facility cases of Taşkesik and Kaynaklar, and quarry case of Özbek). The ways of showing opposition and the strategies used by opposing people had an effect on results of conflicts. For instance, protesters applying for conservation decisions to cancel quarry proposals in Gökdere, Ahmetbeyli and Kösedere managed to stop the unwanted decisions.

Impacts and intensity of conflicts had mutual effects. Whereas tiring and psychological effects increased the intensity of conflicts (i.e. solid waste facility case of Harmandalı, fishery case of Sığacık and quarry case of Yağcılar), the intensity increased political losses in solid waste facility cases and economic costs to companies in fishery and quarry cases. The unusual impact on headman threatened by mining company decreased the possibility of conflict resolution because of tense relationships in one quarry case.

The intensity of conflicts is also related with reasons. When the impacts of LULUs got worse (i.e. extreme damages in quarry case of Germiyan in which stones burst from quarries came to school garden and damaged the walls and windows of houses), the opposing voices got raised. Not only local impacts but also general environmental effects (i.e. eradication of species) increased the intensity of conflicts by inclusion of external environmental groups in the process (i.e. fishery case of Sığacık).

The reasons taking place in legislations had a strong effect on cancellation of LULU decisions and resolution of conflicts, at least for a while. Proximity to olive groves stopped the LULU proposals in some cases (i.e. quarry case of Yağcllar and solid waste facility of Taşkesik); however, these cancellations do not solve the conflicts in every situation (i.e. the quarry companies in Yağcılar took 
Table 2

Index of Conflicts in Case Studies.

\begin{tabular}{|c|c|c|c|c|}
\hline \multirow[t]{2}{*}{ Conflicts } & \multicolumn{4}{|l|}{ Cases } \\
\hline & In all 3 LULU cases & In solid waste facility cases & In fishery cases & In quarry cases \\
\hline Parties in the process & $\begin{array}{l}\text { - Public institutions, hosting } \\
\text { or neighboring } \\
\text { municipalities, local people, } \\
\text { NGOs, private sector and } \\
\text { universities }\end{array}$ & - Metropolitan Municipality & $\begin{array}{l}\text { - Local fishermen, secondary } \\
\text { housing owners and tourism } \\
\text { sector }\end{array}$ & $\begin{array}{l}\text { - Rival companies as } \\
\text { supporters of protesters }\end{array}$ \\
\hline Ways of showing opposition & $\begin{array}{l}\text { - Mobilizations, petitions, } \\
\text { lawsuits, attracting media } \\
\text { attention }\end{array}$ & $\begin{array}{l}\text { - Establishing an initiative } \\
\text { group, contacting with } \\
\text { Ministers and closing roads }\end{array}$ & $\begin{array}{l}\text { - Disturbing EIA meetings, } \\
\text { keeping guard in the sea }\end{array}$ & $\begin{array}{l}\text { - Establishing civil initiatives, } \\
\text { applying for conservation } \\
\text { decisions to cancel quarry } \\
\text { proposals }\end{array}$ \\
\hline Reasons for conflicts & $\begin{array}{l}\text { - Effects of LULUs depending } \\
\text { on type and location, } \\
\text { especially when there are } \\
\text { sensitive neighboring land } \\
\text { uses (pollution, health } \\
\text { effects, etc.) } \\
\text { - Top-down decision making } \\
\text { process full of investigation } \\
\text { deficiencies } \\
\text { - Symbolic participation in EIA } \\
\text { process } \\
\text { - Involvement of powerful } \\
\text { political actors to } \\
\text { manipulate the decisions } \\
\text { - Temporal deficiencies } \\
\text { - Inconsistency with upper } \\
\text { scale plans } \\
\text { - Lack of knowledge about } \\
\text { technology and } \\
\text { characteristics of LULUs } \\
\text { - Effect of media } \\
\text { - Prejudice } \\
\text { - Distrust } \\
\text { - Existing bad examples }\end{array}$ & & $\begin{array}{l}\text { - Exclusion of affected people } \\
\text { out of formal boundaries } \\
\text { - Planners' exclusion in } \\
\text { decision making process } \\
\text { - Disagreement about } \\
\text { polluting effects } \\
\text { - Expecting job opportunities }\end{array}$ & $\begin{array}{l}\text { - Planners' exclusion in } \\
\text { decision making process } \\
\text { - Forcing approaches of } \\
\text { companies } \\
\text { - Expecting job opportunities } \\
\text { and personal economic } \\
\text { benefits }\end{array}$ \\
\hline Impacts of conflicts & $\begin{array}{l}\text { - Fear, psychological effects, } \\
\text { invectives to public officers }\end{array}$ & - Political losses & - Economic costs to companies & $\begin{array}{l}\text { - Economic costs to companies } \\
\text { and threats to headmen by } \\
\text { mining companies }\end{array}$ \\
\hline Solution Attempts & $\begin{array}{l}\text { - EIA public meetings } \\
\text { - Considering technical } \\
\text { criteria } \\
\text { - Communication with parties } \\
\text { but after the decision made } \\
\text { - EIA report signed by various } \\
\text { experts from various } \\
\text { disciplines }\end{array}$ & $\begin{array}{l}\text { - Rehabilitation of existing site } \\
\text { and proposing a } \\
\text { "prestigious" recreational } \\
\text { area } \\
\text { - Proposing a new facility with } \\
\text { improved technology } \\
\text { - Face-to-face meetings with } \\
\text { local people and chambers } \\
\text { but for persuasion } \\
\text { - Site visits with chambers } \\
\text { and university } \\
\text { - A trip abroad for good } \\
\text { examples }\end{array}$ & $\begin{array}{l}\text { - Participatory meeting for } \\
\text { potential sites but full of } \\
\text { criticism } \\
\text { - Transfer to deeper water }\end{array}$ & $\begin{array}{l}\text { - Transfer to more acceptable } \\
\text { locations } \\
\text { - Proposing "wanted" facilities } \\
\text { such as café } \\
\text { - Giving money } \\
\text { - Promising explosion hours, } \\
\text { dust prevention systems and } \\
\text { repairing of the damaged } \\
\text { roads } \\
\text { - Proposing gifts to local } \\
\text { people such as investments } \\
\text { to the schools or mosques, } \\
\text { construction materials and } \\
\text { employment opportunities }\end{array}$ \\
\hline
\end{tabular}

licenses for a neighboring area again and the conflict remained unsolved). Procedural reasons including distrust, lack of knowledge and top-down decision making process also affected the intensity of conflicts. The involvement of powerful political actors and Ministers in the process (i.e. solid waste facility of Taşkesik) increased the recognition of the conflicts out of urban boundaries. On the other hand, the conflicts involving local people expecting job opportunities and personal economic benefits could be solved relatively easier by using attempts of several compensation types such as proposing gifts to local people such as investments to the schools or mosques, construction materials and employment opportunities (i.e. some quarry cases).

There were many solution attempts of decision makers decreasing the intensity of conflicts. Transfer to deeper water in fishery cases and transfer to more acceptable locations in quarry cases are examples. A trip abroad for good examples in solid waste facility case of Taşkesik was seen as an attempt decreasing conflicts by some interviewees whereas some other interviewees told it made no difference.

It would be reduced evaluation to say one LULU type was more intense than other; however, there are several circumstances explaining intensity comparison of 3 LULU types in İzmir. In terms of the year the protests started, quarries faced the longest conflict process started in 1992 with Belkahve case and solved in 2010 with the transfer of quarries. As another circumstance location variety made the solid waste facility cases having the most intense conflicts. Solid waste facility cases faced conflicts in every trial of alternative locations for only "one" land use decision; while fish- 
eries and quarries faced conflicts for different land use decisions in their own locations. In terms of having national and international support, the fishery cases gained the first rank in conflict intensity with Sığacık case in which protesters came from different cities and the Italian "father of Citta Slow" signed the "no to tunny fisheries in Sığacık" campaign. Indeed, conflict intensities had varieties in cases in the same LULU types.

\section{Conclusion}

There are various reasons for LULU conflicts in İzmir. Findings of the case studies demonstrate that the reasons for conflicts mainly include external effects of LULUs on local people by increasing density, pollution and traffic; for instance odor of solid waste facilities, visual pollution of fisheries and dust and vibration effects of quarries. The most usual source of conflicts about LULUs is environmental stress, because planning is about resource allocation and when there is an urban land scarcity, the local people act against large projects. Decision makers in all cases paid attention to technical requirements for the facilities within legal framework; however there are problems about proposed locations within scientific framework. There are also procedural reasons for conflicts including top-down decisions, symbolic participation, lack of investigation, effect of political actors, inconsistency with regulations and lack of transparent process.

The conflicts resulted not only with negative and but also with positive impacts. The negative impacts are fear, tiring and psychological effects, negative attitudes to public officers, political loses of decision makers and economic costs due to moving or closing the facility. Positive impacts and social benefits are withdrawal of the wrong location decisions on sensitive areas, collectively acting of local people in villages, personal and political benefits, increase in organization level of mobilizations against LULUs with the support of NGOs, political actors, universities and private sector.

Comparative survey on the reasons for conflicts on three LULU types in Izmir indicates that there are both varieties and similarities. While solid waste facilities and quarries are regarded as needs, fisheries are regarded as 'not necessity' and unwanted because of this. The impacts of quarries and solid waste facilities are perceived more certain than those of fisheries since there is a disagreement in the polluting effects of fisheries. The procedural reasons are similar in all three LULU cases except the locality of the responsible institution and the role of planner. The solid waste facility decisions are made by a commission including planners in local municipality whereas fisheries and quarries proposed by private companies are decided with permissions given by the public institutions no matter having a planner. These procedures increase conflicts in fishery and quarry cases.

For effective solution substantive and procedural issues should be considered together. Decision makers in all İzmir cases did not pay attention to procedural reasons as much as substantive reasons. Participatory approaches could not be successfully managed as the regulations do not mandate participatory processes. This does not mean that no effort was made. It is found that some conflict resolution methods are used by decision makers including attempts such as communication with stakeholders, face-to-face meetings and engagement with chambers and experts in solid waste facility case, participatory meeting in fishery case and suggesting gifts to possible local opponents in quarry case; however, the opponents were not satisfied with these attempts as it was done after the decisions made.

The participatory approaches in planning processes may minimize and resolve conflicts in such case studies. The conflict facing location decisions may be renewed to minimize effects to the environment, the society and the individuals even if not remov- ing all negative impacts. A process providing support from all related parties and ensuring their comprehension of the solution opportunities and limitations may resolve conflicts and bring proper decisions. In this context, planners ' responsibilities become important as they should inform and support the education of the participants to planning process and act as mediators in conflict resolution processes. The solution proposals could be tried for İzmir or similar cases. However each practice needs its own solution depending on multiple factors and temporal circumstances. A further study evaluating the results of this trial would be complementary.

\section{Acknowledgements}

İzmir Institute of Technology provided financial support in the data collection process of this research as a Scientific Research Project with number 2013-iYTE-35. A part of this research, the planning process of solid waste facilities in İmir, was presented in the 26th International Annual Congress of AESOP (The Association of European Schools of Planning) in Ankara in June 2012 and a paper in Turkish was presented in City Symposium (İzmir 2. Kent Sempozyumu) in İzmir in November 2013.

\section{Appendix A.}

English Translation of the Interview Questions ( $\mathrm{L}$ in the questions indicate the name of the location or village hosting the land use, for example Harmandalı)

1. Which stage(s) of the process (site selecting, protesting decisions, finding solutions) of the solid waste facilities/fisheries/quarries in L did you (individually or institutionally) participate?

2. Do you know how the sites of solid waste facilities/fisheries/quarries in L are selected by whom? Could you explain if you know?

3. Do you think this site selection decision was right? Why?

4. Do you think the site selection method was successful? Why? (Was it participatory, just, etc.)

5. Who opposes and who supports the solid waste facilities/fisheries/quarries in L? (Are they local or external? Are they individual or organized?)

6. How many people are there in these conflict processes?

7. What are the opposition reasons of different opponents for the solid waste facilities/fisheries/quarries in L? (Damage to environment, damage to health, etc.)

8. What kind of factors affected the opposition in addition to the damages of solid waste facilities/fisheries/quarries? (Lack of knowledge, political reasons, media, lack of trust, etc.)

9. Do you think the reason for opposition is the selection of wrong site or wrong decision making method or both?

10. Why did the non-opponents not oppose? (Were they happy, threatened, got money, etc.)

11. How did the opponents show their responses? (What kind of meeting did they organize? Were there lawsuits?)

12. If the solid waste facilities/fisheries/quarries in L are cancelled, were the reasons for cancellations the movements or other reasons?

13. What were the main subjects of this conflict process? (Environment, property ownership, participation, etc.)

14. Was anybody harmed in this conflict process?

15. How were the approaches of parties to conflict resolution? (Forcing, collaborating, etc.)

16. What did the decision makers do for resolving conflicts? (Face to face meetings, proposing compensation, etc.) 
17. Do you think the attempts of decision makers for conflict resolution were sufficient and efficient? If not, what should be done?

18. Would you like to add anything else?

19. What do you think about the conflicts in site selection processes of other LULUs in various locations in İzmir? (Thermal plants, wind energy plants, watching towers, etc.)

\section{References}

Andrew, J.S., 2001. Examining the claims of environmental ADR: evidence from waste management conflicts in Ontario and Massachusetts. J. Plan. Educ. Res. 21 (2), 166-183, http://dx.doi.org/10.1177/0739456X0102100205.

Atay Kaya, İ., 2014. Conflicts in the Planning Processes of Locally Unwanted Land Uses (LULUs): Case Studies in İzmir. İzmir Institute of Technology. Doctor of Philosophy, İmir, pp. 262.

Banar, M., Kose, B.M., Ozkan, A., Poyraz Acar, I., 2006. Choosing a municipal landfill site by analytic network process. Environ. Geol. 52, 747-751, http://dx.doi.org 10.1007/s00254-006-0512-x.

Bassett, K., Griffiths, R., Smith, I., 2002. Testing governance: partnerships planning and conflict in waterfront regeneration. Urban Stud. 39 (10), 1757-1775, http://dx.doi.org/10.1080/0042098022000002948.

Baxter, J., Eyles, J., Elliott, S., 1999. From siting principles to siting practices: a case study of discord among trust, equity and community participation. J. Environ. Plan. Manage. 42 (4), 501-525, http://dx.doi.org/10.1080/09640569911037.

Been, V., 1994. Locally undesirable land uses in minority neighborhoods disproportionate siting or market dynamics. Yale Law J. 103 (6), 1383-1422.

Campbell, D.J., Gichohi, H., Mwangi, A., Chege, L., 2000. Land use conflict in Kajiado district, Kenya. Land Use Policy 17 (4), 337-348.

Carpenter, S., 1999. Choosing appropriate consensus building techniques and strategies. In: Susskind, L., McKearnan, S., Thomas-Larmer, J. (Eds.), The Consensus Building Handbook: A Comprehensive Guide to Reaching Agreement. Sage Publications, Thousand Oaks, London and New Delhi, pp. 61-98, Chapter 1.

Chabot, M., Duhaime, G., 1998. Land-use planning and participation: the case of inuit public housing (Nunavik, Canada). Habitat Int. 22 (4), 429-447.

Chiou, C.T., Lee, J., Fung, T., 2011. Negotiated compensation for NIMBY facilities: siting of incinerators in Taiwan. Asian Geogr. 28 (2), 105-121, http://dx.doi. org/10.1080/10225706.2011.623407.

Chung, J.B., Kim, H.-K., Rho, S.K., 2008. Analysis of local acceptance of a radioactive waste disposal facility. Risk Anal. 28 (4), 1021-1032, http://dx.doi.org/10. 1111/j.1539-6924.2008.01074.x.

Cullen, D., McGee, G.J.A., Gunton, T.I., Day, J.C., 2010. Collaborative planning in complex stakeholder environments: an evaluation of a two-tiered collaborative planning model. Soc. Nat. Resour. 23 (4), 332-350, http://dx.doi. org/10.1080/08941920903002552.

Cutter, S.L., 1995. Race, class and environmental justice. Prog. Hum. Geogr. 19 (1), 111-122, http://dx.doi.org/10.1177/030913259501900111.

Ehrmann, J.R., Stinson, B.L., 1999. Joint fact-finding and the use of technical experts In: Susskind, L., McKearnan, S., Thomas-Larmer, J. (Eds.), The Consensus Building Handbook: A Comprehensive Guide to Reaching Agreement. Sage Publications, Thousand Oaks, London and New Delhi, pp. 375-400, Chapter 9.

Ekmekcioglu, M., Kaya, T., Kahraman, C., 2010. Fuzzy multicriteria disposal method and site selection for municipal solid waste. Waste Manage. 30, 1729-1736.

Elliott, M., Stiftel, B., Frank, K., Mayere, S., Jones, R. M., Taylor, T., 2003. Societal Effects of Collaborative Decision-Making in Florida: The Impact of Environmental Conflict Resolution Institutions on Public Choice, Civic Culture and Environmental Management Systems.

Elliott, M.L.P., 1999. The role of facilitators, mediators, and other consensus building practitioners. In: Susskind, L., McKearnan, S., Thomas-Larmer, J. (Eds.), The Consensus Building Handbook: A Comprehensive Guide to Reaching Agreement. Sage Publications, Thousand Oaks, London and New Delhi, pp. 199-240, Chapter 5.

Fainstein, S.S., 2000. New directions in planning theory. Urban Aff. Rev. 35 (4), 451-478.

Forester, J., 1999. The Deliberative Practitioner: Encouraging Participatory Planning Processes. MIT Press, Massachusetts.

Goldstein, B.E., Butler, W.H., 2010. Expanding the scope and impact of collaborative planning. J. Am. Plan. Assoc. 76 (2), 238-249, http://dx.doi.org/ $10.1080 / 01944361003646463$

Healey, P., 2003. The communicative turn in planning theory and its implications for spatial strategy formation. In: Campbell, S., Fainstein, S.S. (Eds.), Readings in Planning Theory. , 2nd ed. Blackwell Publishing, Cambridge, pp. 237-255.

Innes, J.E., Booher, D.E., 1999. Consensus building as role playing and bricolage: toward a theory of collaborative planning. J. Am. Plan. Assoc. 65 (1), 9, http:// dx.doi.org/10.1080/01944369908976031.

Ishizaka, K., Tanaka, M., 2003. Resolving public conflict in site selection process- a risk communication approach. Waste Manage. 23 (5), 385-396, http://dx.doi. org/10.1016/S0956-053X(03)00094-1.

Jones, C., Baker, M., Carter, J., Jay, S., Short, M., Wood, C., 2005. Strategic Environmental Assessment and Land Use Planning An International Evaluation. Sterling, VA, Earthscan, London.
Kaiser, E.J., Godschalk, D.R., Chapin Jr., F.S., 1995. Urban Land Use Planning, 4th ed. The University of Illinois Press, Urbana and Chicago, IL.

Kaliampakos, D., Mavrikos, A., Menegaki, M., 2011. Construction industry and archaeology: a land-use conflict on the island of Andros, Greece. Int. J. Min. Reclam. Environ. 25 (2), 152-160, http://dx.doi.org/10.1080/17480930.2010. 538546.

Kikuchi, R., Gerardo, R., 2009. More than a decade of conflict between hazardous waste management and public resistance: a case study of NIMBY syndrome in Souselas (Portugal). J. Hazard. Mater. 172 (2-3), 1681-1685, http://dx.doi.org/ 10.1016/j.jhazmat.2009.07.062.

Klosterman, R.E., 2003. Arguments for and against planning. In: Campbell, S. Fainstein, S.S. (Eds.), Readings in Planning Theory. , 2nd ed. Blackwell Publishing, Cambridge, pp. 86-101.

Kunreuther, H., Susskind, L.E., Aarts, T.D., 1991. Facility Siting Credo: Guidelines for an Effective Facility Siting Process. Publication Services, University of Pennsylvania.

Kunreuther, H., Fitzgerald, K., Aarts, T.D., 1993. Siting noxious facilities: a test of the facility siting credo. Risk Anal. 13 (3), 301-318.

Lam, K.C., Woo, L.Y., 2009. Public perception of locally unwanted facilities in Hong Kong: implications for conflict resolution. Local Environ. 14 (9), 851-869, http://dx.doi.org/10.1080/13549830903160621.

Lesbirel, S.H., 2011. Project siting and the concept of community. Environ. Polit. 20 (6), 826-842, http://dx.doi.org/10.1080/09644016.2011.617168.

Levy, J.M., 2000. The Tools of Land-Use Planning. In New York Contemporary Urban Planning, 5th ed. Prentice Hall, Chapter 9.

Llurdes, J.C., Sauri, D., Cerdan, R., 2003. Ten years wasted: the failure of siting waste facilities in central Catalonia, Spain. Land Use Policy 20 (4), 335-342, http://dx. doi.org/10.1016/S0264-8377(03)00057-7.

Müezzinoğlu, A., 2000. A mediation case for resolving the energy and İzmir, Turkey environment dispute at aliağa. Environ. Manage. 26 (1), 47-57, http://dx.doi. org/10.1007/s002670010070.

Margerum, R., 2002. Evaluating collaborative planning. J. Am. Plan. Assoc. 68 (2), 179, http://dx.doi.org/10.1080/01944360208976264.

McCorkle, S., Reese, M.J., 2005. Mediation Theory and Practice. Pearson Education, Boston.

Milliyet, all related news from the web-based search of the newspaper between 2004 and 2012. [online] Available at: http://www.milliyet.com.tr/ (accessed April 2012).

Nordenstam, B.J., 1994. When Communities Say NIMBY to Their LULUs: Factors Influencing Environmental and Social Impact Perception Social Ecology University of California. Doctor of Philosophy, Irvine, pp. 190

O’Hare, M., Bacow, L., Sanderson, D., 1983. Facility Siting and Public Opposition. Van Nostrand Reinhold, New York.

Ozawa, C.P., 1999. Making the best use of technology. In: Susskind, L., McKearnan, S., Thomas-Larmer, J. (Eds.), The Consensus Building Handbook: A Comprehensive Guide to Reaching Agreement. Sage Publications, Thousand Oaks, London and New Delhi, pp. 401-438, Chapter 10.

Ozcevik, O., Beygo, C., Akcakaya, I., 2010. Building capacity through collaborative local action: case of matra REGIMA within Zeytinburnu regeneration scheme. J. Urban Plann. Dev., 169-175, http://dx.doi.org/10.1061/(asce)07339488(2010)136:2(169).

Palabıyık, H., Yavas, H., Aydın, M., 2010. Nükleer Enerji ve Sosyal Kabul Sorunu: NIMBY Sendromu Üzerine Kritik bir Literatür İncelemesi (Nuclear Energy and Social Acceptance Problem: A Critical Literature Review on NIMBY Syndrome). Süleyman Demirel Üniversitesi İktisadi ve İdari Bilimler Fakültesi Dergisi 15 (1), 45-66.

Peltonen, L., Sairinen, R., 2010. Integrating impact assessment and conflict management in urban planning: experiences from Finland. Environ. Impac Assess. Rev. 30 (5), 328-337, http://dx.doi.org/10.1016/j.eiar.2010.04.006.

Peyton, B., 2007. Rethinking Spatial Conflict: An Analysis of LULUs and Their Encroaching Communities. Urban and Environmental Policy and Planning. Tufts University. Master of Arts, pp. 56

Popper, F.J., 1983. LP/HC and LULUs: the political uses of risk analysis in land-Use planning. Risk Anal. 3, 255-263, http://dx.doi.org/10.1111/j.1539-6924.1983. tb01394.x.

Popper, F.J., 1985. The environmentalist and the LULU. Environment 27 (2), 6-11, Cover story.

Roberts, T., 1988. Land use planning. In: Catanese, A.J., Snyder, J.C. (Eds.), Urban Planning. , 2nd ed. McGraw-Hill, New York, Chapter 10

Rogge, E., Dessein, J., Gulinck, H., 2011. Stakeholders perception of attitudes towards major landscape changes held by the public: the case of greenhouse clusters in Flanders. Land Use Policy 28 (1), 334-342, http://dx.doi.org/10. 1016/j.landusepol.2010.06.014.

Schively, C., 2007. Understanding the NIMBY and LULU phenomena: reassessing our knowledge base and informing future research. J. Plan. Lit. 21 (3), 255-266, http://dx.doi.org/10.1177/0885412206295845.

Sellers, M.P., 1993. NIMBY: a case study in conflict politics. Public Adm. Q. 16 (Winter (4)), 460-477.

Simsek, C., Elci, A., Gunduz, O., Taskin, N., 2014. An improved landfill site screening procedure under NIMBY syndrome constraints. Landsc. Urban Plan. 132, 1-15.

Steelman, T.A., Carmin, J., 1998. Common property, collective interests, and community opposition to locally unwanted land uses. Soc. Nat. Resour. 11 (5), 485-504, http://dx.doi.org/10.1080/08941929809381096.

Straus, D., 1999. Managing meetings to build consensus. In: Susskind, L., McKearnan, S., Thomas-Larmer, J. (Eds.), The Consensus Building Handbook: A 
Comprehensive Guide to Reaching Agreement. Sage Publications, Thousand Oaks, London and New Delhi, pp. 241-286, Chapter 7.

Susskind, L., Cruikshank, J., 1987. Introduction Breaking the Impasse: Consensual

Approaches to Resolving Public Disputes. Basic Books, New York: NY, pp. 3-15.

Susskind, L.E., Cruikshank, J.L., 2006. Breaking Roberts Rules: The New Way to Run Your Meeting Build Consensus, and Get Results. Oxford University Press, Kindle edition.

Susskind, L., McKearnan, S., Thomas-Larmer, J., 1999. Introduction. In: Susskind, L. McKearnan, S., Thomas-Larmer, J. (Eds.), The Consensus Building Handbook: A Comprehensive Guide to Reaching Agreement. Sage Publications, Thousand Oaks, London and New Delhi, pp. xvii-xxii.

TurkStat, 2015. Address Based Population Registration System. Turkish Statistical Institute.
Vasiloglou, V.C., 2004. New tool for landfill location. Waste Manage. Res. 22, 427-439.

von der Dunk, A., Grêt-Regamey, A., Dalang, T., Hersperger, A.M., 2011. Defining a typology of peri-urban land-use conflicts - a case study from Switzerland. Landsc. Urban Plan., http://dx.doi.org/10.1016/j.landurbplan.2011.02.007.

Whetten, D.A., Cameron, K.S., 2011. Managing conflict. In: Yagan, S. (Ed.), Developing Management Skills. , 8th ed. Prentice Hall, Pearson, New Jersey, pp. 373-437, Chapter 7.

Yılmaz, M.E., 2012. Türkiye'de Arabuluculuk Uygulamaları (Mediation Practices in Turkey). İnsan ve Toplum Bilimleri Araștırmaları Dergisi 1 (3), 7-16. 